\title{
Bioconcentration efficiency of Lemna minor L. and Lemna gibba L. for trace metals in three southeastern Bulgarian water reservoirs
}

Katya Velichkova

Department of Biology and Aquaculture, Agricultural Faculty, Trakia University, Students Campus, 6000 Stara Zagora, Bulgaria.

\begin{abstract}
Correspondencia
K. Velichkova

E-mail: genova@abv.bg

Received: 17 April 2017
\end{abstract}

Accepted: 25 January 2018

Published on-line: 1 February 2019

\section{Resumen}

Eficiencia de bioconcentration de Lemna minor L. and Lemna gibba L. para metales traza en tres embalses del sureste de Bulgaria

La lenteja de agua se utiliza en el tratamiento de aguas residuales para eliminar sustancias nocivas, minerales y contaminación orgánica. El propósito del presente estudio fue investigar la eficiencia de bioconcentración de metales pesados en Lemna minor y Lemna gibba provenientes de tres embalses del sureste de Bulgaria: el canal de la ciudad de Elhovo, el canal del lago Vaja y el canal del lago Mandra. Se analizaron los contenidos de proteína cruda, lípidos y ceniza en las especies estudiadas de Lemna. Los metales pesados en agua y plantas acuáticas se determinaron con un espectrómetro de absorción atómica (AAS) "A Analyst 800" Perkin Elmer. Las concentraciones de metales en $L$. minor y $L$. gibba mostraron una tendencia descendente: $\mathrm{Mn}>\mathrm{Fe}>\mathrm{Zn}>\mathrm{Cu}>\mathrm{Ni}>$ $\mathrm{Cr}>\mathrm{Pb}>\mathrm{Cd}$ en las tres masas de agua.

Palabras clave: Bioconcentración; Metales pesados; Lemna minor; Lemna gibba; Proteínas.

\begin{abstract}
Duckweed is used in wastewater treatment to remove inorganic substances, mineral and organic contamination. The purpose of present study was to investigate a Lemna minor and Lemna gibba bioconcentration efficiency of trace metals in three southeast Bulgarian water reservoirs. Three waterbodies located on the territory of South East Bulgaria: water canal town Elhovo, water canal Vaja Lake and water canal Mandra Lake was studied. Crude protein, lipid, ash content in studied species of Lemna were analyzed. The trace metal content in water and aquatic plants was determined on an atomic absorption spectrometer (AAS) "A Analyst 800" - Perkin Elmer. The concentrations of metals in both L. minor and L. gibba and for all sites showed a downward trend: $\mathrm{Mn}>\mathrm{Fe}>$ $\mathrm{Zn}>\mathrm{Cu}>\mathrm{Ni}>\mathrm{Cr}>\mathrm{Pb}>\mathrm{Cd}$.
\end{abstract}

Key words: Bioconcentration; Heavy metal; Lemna minor; Lemna gibba; Protein. 


\section{Introduction}

The population of the land is constantly increasing which lead an increased anthropogenic impact on the biosphere. Pollutants such as heavy metals, oil and grease, phenols, sulphide, sulphate, nitrate, phosphate, dissolved solids, suspended solids impact negatively on the environment (Patel \& Kanungo 2010, Nayyef et al. 2012). These elements in the state of ions, penetrating into the body of the hydrobionates, have a powerful toxic effect, most often as denaturation of important enzyme and transport proteins. Different plants are increasingly used to accumulate and remove pollution from water, soil and air (Gijzen \& Kondker 1997). This is eco and efficient technology in which natural properties of the plant are used to remove harmful substances from wastewater $(\mathrm{Pa}-$ tel \& Kanungo 2010, Ugya 2015). Aquatic plants respond even to temporary deviations of the chemical and physical reference values, which is sufficient to suggest that these organisms could be used as an important biological marker for the purity of a given hydro-ecosystem. One of the most common hydrobionites that serve as a filter for toxins of a different nature is the species of the genus Lemna L. (Chaudhary \& Sharma 2014, Axtell et al. 2003). This species has been successfully used to assess the heavy metal content of freshwater ecosystems. Lemna minor L. and Lemna gibba L. are aquatic plants floating on the surface of still or slow-moving fresh water bodies and often form dense floating mats in eutrophic ditches and ponds (Driever et al. 2005). These plants adapt easily to different environmental terms. They have high protein content and are a source of food for waterfowl, fish, and small invertebrates and provide habitat for a number of small organisms (Van Hoeck et al. 2015). It is therefore very important to analyze how much of the pollution in the Lemna pool accumulates in its tissues. Duckweed is also used in wastewater treatment to remove mineral and organic contamination (Velichkova et al. 2017). It has a high metal accumulation potential, which is particularly important for local dirt. It is considered a reliable bioindicator for both passive and active biomonitoring of water bodies (Jayasri \& Suthindhiran 2017). The purpose of present study was to investigate the L. minor and L. gibba bioconcentration efficiency for heavy metals of three southeastern Bulgarian water reservoirs.

\section{Materials and methods}

\section{Plant material and water}

Three water-bodies located on the territory of South East Bulgaria: water canal town Elhovo (Tundzha River) (42 $\left.09^{\prime} 57^{\prime \prime} \mathrm{N}, 26^{\circ} 33^{\prime} 23^{\prime \prime} \mathrm{E}\right)$, water canal Vaja Lake $\left(42^{\circ} 30^{\prime} 37^{\prime \prime} \mathrm{N}, 27^{\circ} 24^{\prime} 17^{\prime \prime} \mathrm{E}\right)$, water canal Mandra Lake $\left(42^{\circ} 24^{\prime} 43^{\prime \prime N}, 2^{\circ} 20^{\prime} 24^{\prime \prime E}\right)$ were studied. These water-bodies pass through big settlements, industrial and agricultural regions and is a precondition for their pollution with toxicants of different nature. Waters of these water-bodies are used for irrigation and fish farming.

Water samples from the studied water bodies were collected on June 2016 in accordance with the requirements of EN ISO 5667-1/2007. Water samples were collected from a depth of $0.5-1 \mathrm{~m}$ using 1.5 L PET bottles. The water samples were stored in accordance with EN ISO 5667 - 3/2006. The measurement of $\mathrm{pH}$, temperature and conductivity was made with a portable combined meter and with a $\mathrm{pH}$ probe (Hach Lange, Germany). Other analyzed hydrochemical parameters ammonium $\left(\mathrm{mg} \mathrm{l}^{-1}\right)$, nitrites $\left(\mathrm{mg} \mathrm{l}^{-1}\right)$, nitrates $\left(\mathrm{mg} \mathrm{l}^{-1}\right)$, and phosphate $\left(\mathrm{mg} \mathrm{l}^{-1}\right)$ were measured spectrophotometrically with a spectrophotometer DR 2800 (Hach Lange, Germany) with appropriate cuvette tests (Hach Lange, 2007).

The samples of the studied aquatic plants from water bodies were collected, stored and analyzed. From each pond plant samples were put in clean plastic water tanks $(10 \mathrm{~L})$ and labeled carefully by permanent marker. In the laboratory, the plant material (10 g) was washed carefully to remove dirt, sludge, and other adhesive debris from it. All the collected plant samples were placed in newspapers for the absorption of excess water and dried.

Water and aquatic plants samples were analyzed in the laboratories of the Environment Research Center at the Faculty of Agriculture, Trakia University, Stara Zagora, Bulgaria.

\section{Experimental method}

Crude protein content (\%) was calculated by converting the nitrogen content, quantify by Kjeldahl's method, using an automatic Kjeldahl system (Kjeltec 8400, FOSS, Sweden). Lipid content (\%) was determined by the method of Soxhlet, using an automatic system (Soxtec 2050, FOSS, Sweden). Ash content (\%) was investigated by in- 
cineration in a muffle furnace (MLW, Germany) at $550{ }^{\circ} \mathrm{C}$ for $8 \mathrm{~h}$. Crucibles were brought about the room temperature and weighed.

The heavy metal in water and aquatic plants was determined on an atomic absorption spectrometer (AAS) "A Analyst 800" - Perkin Elmer. Analyses for heavy metal in surface water samples were conducted in graphite tube or flame (depending on the concentration of these elements), at a definite wavelength and preliminary preservation of water in samples with $5 \mathrm{~cm}^{3}$ concentrated $\mathrm{HNO} 3$ per sample (ISO 8288, BS EN ISO 5667-3/2006). The contents of heavy metal in water samples were measured in $\mathrm{mg} \mathrm{kg}^{-1}$. The capacity of plants to absorb and accumulate metals from the water was evaluated using their bioconcentration factor $(\mathrm{BCF})$. $\mathrm{BCF}$ was calculated as the ratio of the concentrations of metals in aquatic plant and water (Hawker \& Connell 1991): BCF = [Metal] plant / [Metal] water .

The samples of aquatic plants were prepared for analysis by combustion in a microwave oven Perkin Elmer Multiwave 3000. The extracts were extended up to $25 \mathrm{ml}$ with distilled water. The metal concentrations in the acid solutions were amended of AAS in accordance with ISO 11047. The concentrations of the investigated element of aquatic plants were expressed as $\mathrm{mg} \mathrm{kg} \mathrm{kg}^{-1}$ dry weight.

The instrument was periodically calibrated with standard chemical solutions prepared from commercially available chemicals (Merck, Germany). An air-acetylene flame and hollow cathode lamp for all samples were used. Calibration curves were prepared using dilutions of stock solutions. The samples (water and aquatic plants) were measured three times and the mean values were calculated.

Data analyses were conducted by using oneway Analysis of Variance ANOVA (MS Office, 2010)

\section{Results and discussion}

The results of the chemical composition of the studied duckweed are given in table 1.

The highest amount of protein was measured in $L$. minor $(21.80 \%)$, which was $14.2 \%$ more than the least measured in L. gibba (18.71). With

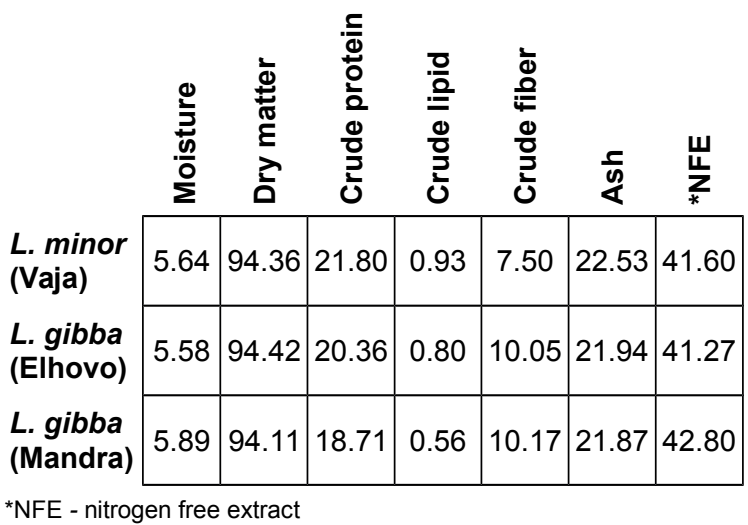

Tabla 1. Composición química de L. minor y L. gibba en los cuerpos de agua estudiados. En porcentaje.

Table 1. Chemical composition of L. minor and L. gibba in the studied water bodies. As percentage.

regard to crude lipid $L$. minor has higher quantity lipids $(0.93 \%)$, which is $30 \%$ more than $L$. gibba. The content of NFE is a little higher in $L$. gibba. With regard to the raw fiber is observed at a large quantity in $L$. gibba $(10.17 \%)$, and less in L. minor $(7.50 \%)$. All these results show the good nutritional value of species of the genus Lemna and are prerequisite for their use in food rations of fish, birds, swine and other animals (Drost et al., 2007).

The chemical composition of the water of the Vaja, Elhovo, Mandra are presented in a table 2.

According to various authors (Chawla et al. 1991, Körner et al. 2001, Kaur et al. 2013), there is a correlation between the values of $\mathrm{pH}$, temperature and the accumulation of heavy metals of

\begin{tabular}{|c|c|c|c|c|c|c|c|}
\hline & $\mathrm{pH}$ & $\begin{array}{c}\text { Temperature } \\
{ }^{\circ} \mathrm{C}\end{array}$ & $\begin{array}{l}\text { Conductivity } \\
\mu \mathrm{S} \mathrm{cm}^{-1}\end{array}$ & $\begin{array}{l}\mathrm{NH}_{4}^{+} \\
\mathrm{mg} \mathrm{l}^{-1}\end{array}$ & $\begin{array}{l}\mathrm{NO}_{3}^{-} \\
\mathrm{mg} \mathrm{l}^{-1}\end{array}$ & $\begin{array}{l}\mathrm{NO}_{2}^{-} \\
\mathrm{mg} \mathrm{l}^{-1}\end{array}$ & $\begin{array}{l}\mathrm{PO}_{4}^{-} \\
\mathrm{mg} \mathrm{l}^{-1}\end{array}$ \\
\hline & $6.46 \pm$ & 2 & $109 \pm 8$ & $0.041 \pm 0.11$ & $0.038 \pm 0.01$ & $0.003 \pm 0.002$ & $0.36 \pm 0.03$ \\
\hline & $6.27 \pm 0.2$ & 22 & & 01 & 01 & 0.0 & $0.38 \pm 0.02$ \\
\hline andra & $6.32 \pm 0.1$ & $23 \pm 0.02$ & $116 \pm 5$ & $0.04 \pm 0.02$ & $0.042 \pm 0.02$ & $0.003 \pm 0.001$ & $0.35 \pm 0.03$ \\
\hline
\end{tabular}

Tabla 2. Composición química de los cuerpos de agua estudiados. Media \pm SD.

Table 2. Chemical composition of the studied water bodies. Average \pm SD) 


\begin{tabular}{|c|c|c|c|c|c|c|c|c|c|}
\hline & \multicolumn{3}{|c|}{ Vaja } & \multicolumn{3}{|c|}{ Elhovo } & \multicolumn{3}{|c|}{ Lake Mandra } \\
\hline & Water & L. minor & BCF & Water & L. gibba & BCF & Water & L. gibba & BCF \\
\hline $\mathrm{Fe}$ & $0.6630 \pm 0.09$ & $1309.95 \pm 3.43$ & 1975.80 & $1.5630 \pm 0.08$ & $1324.71 \pm 4.9$ & 847.50 & $1.4550 \pm 0.08$ & $1317.26 \pm 4.8$ & 905.30 \\
\hline $\mathrm{Zn}$ & $0.4980 \pm 0.023$ & $90.91 \pm 0.54$ & 182.60 & $0.5210 \pm 0.009$ & $98.07 \pm 40.2$ & 188.20 & $0.6280 \pm 0.009$ & $92.63 \pm 41.2$ & 147.50 \\
\hline $\mathrm{Mn}$ & $0.2750 \pm 0,09$ & $2985.80 \pm 3.53$ & 10857.50 & $0.2610 \pm 0.07$ & $2776.47 \pm 5.3$ & 10637.80 & $0.3480 \pm 0.07$ & $2792.34 \pm 4.6$ & 8024 \\
\hline $\mathrm{Ni}$ & $0.0930 \pm 0.02$ & $0.4678 \pm 0.08$ & 5.03 & $0.0748 \pm 0.025$ & $0.4957 \pm 0.07$ & 6.60 & $0.0657 \pm 0.025$ & $0.4838 \pm 0.07$ & 7.40 \\
\hline $\mathrm{Cu}$ & $0.1260 \pm 0.05$ & $8.93 \pm 2.5$ & 70.90 & $0.1090 \pm 0.04$ & $8.07 \pm 1.6$ & 74.04 & $0.1390 \pm 0.04$ & $9.82 \pm 2.6$ & 70.60 \\
\hline $\mathrm{Pb}$ & $0.0325 \pm 0.014$ & $0.1871 \pm 0.07$ & 5.60 & $0.0267 \pm 0.01$ & $0.1984 \pm 0.04$ & 7.40 & $0.0201 \pm 0.01$ & $0.1935 \pm 0.06$ & 9.60 \\
\hline $\mathrm{Cd}$ & $0.0083 \pm 0.002$ & $0.0465 \pm 0.01$ & 5.61 & $0.0065 \pm 0.002$ & $0.0498 \pm 0.01$ & 7.70 & $0.0051 \pm 0.002$ & $0.0480 \pm 0.03$ & 9.40 \\
\hline $\mathrm{Cr}$ & $0.017 \pm 0.01$ & $0.1997 \pm 0.06$ & 11.70 & $0.017 \pm 0.015$ & $0.2104 \pm 0.08$ & 12.40 & $0.009 \pm 0.015$ & $0.2056 \pm 0.08$ & 22.80 \\
\hline
\end{tabular}

Tabla 3. Concentraciones medias $\left(\mathrm{mg} \mathrm{kg}^{-1}\right) \pm(\mathrm{SD})(\mathrm{n}=3)$ de metales en agua de Vaja, Elhovo y lago Mandra, en $L$. minor y $L$. gibba, y factor de bioconcentración (BCF)(planta/agua) para cada localidad.

Table 3. Average concentrations $\left(\mathrm{mg} \mathrm{kg}^{-1}\right) \pm(\mathrm{SD})(\mathrm{n}=3)$ of metals in water from Vaja, Elhovo and lake Mandra, in $L$. minor and $L$. gibba, and bioconcentration factor $(\mathrm{BCF})$ (plant/water) for every locality.

the species from genus Lemna. The highest bioconcentration potential of heavy metal was observed by Lemna sp. at pH 6 and temperature higher than $22{ }^{\circ} \mathrm{C}$ (Singh et al. 2012). In our studied reservoirs the measured $\mathrm{pH}(6.27-6.46)$ and temperatures $\left(22-23{ }^{\circ} \mathrm{C}\right)$ are close to the optimum for the accumulation of the species. At the level of ammonium and nitrate ions in the water reservoirs 0.04-0.68 $\mathrm{mg}^{-1}$ the accumulation capacity of the Lemna sp. gradually increases (Hammouda et al., 1995). Similar low concentrations of these ions were also measured in our studied ponds.

On the protein content also influences and the amounts of heavy metals in water bodies in which duckweeds are located. Minimal amounts of the metals $\left(0.05 \mathrm{mg} \mathrm{l}^{-1}\right)$ have an inhibitory effect on the protein content (Miranda et al. 2000, Hou et al. 2007). Probably that is the reason for the lower protein content in our tested species compared to the higher values reported for pure cultures.

The concentrations of metals in the L. minor followed a downward trend (Table 3):

$\mathrm{Mn}>\mathrm{Fe}>\mathrm{Zn}>\mathrm{Cu}>\mathrm{Ni}>\mathrm{Cr}>\mathrm{Pb}>\mathrm{Cd}$

The bioconcentration (BCF) capacity of $L$. minor is shown through its bioconcentration factors, indicating a decreasing order as follows:

$\mathrm{Mn}>\mathrm{Fe}>\mathrm{Zn}>\mathrm{Cu}>\mathrm{Cr}>\mathrm{Cd}>\mathrm{Pb}>\mathrm{Ni}$

It is noticeable that the bioconcentration capacity of $L$. minor for $\mathrm{Mn}$ is thousand times higher than it is for the other metals.

There is no difference in the order of the Mn, $\mathrm{Fe}, \mathrm{Zn}$ and $\mathrm{Cu}$ content in a plant compared to the sequence of their bioconcentration ability. The difference in the order of another metal content in a plant compared to the sequence of their accumulation ability can be seen in table 3 . This tendency suggests the different accumulation capacity of macrophytes for certain metals. Plants accumulate certain metals irrespective of their concentrations in the water, which is obviously a characteristic provided by its capacity for the accumulation of each individual element (Kastratović et al. 2015).

The concentrations of metals in the L. gibba followed a downward trend (table 3):

\section{$\mathrm{Mn}>\mathrm{Fe}>\mathrm{Zn}>\mathrm{Cu}>\mathrm{Ni}>\mathrm{Cr}>\mathrm{Pb}>\mathrm{Cd}$}

Comparison of levels of elements in each of the examined groups of plants proved that the highest concentrations of $\mathrm{Mn}, \mathrm{Fe}$, and $\mathrm{Zn}$ are found in L. minor and L. gibba. The bioconcentration (BCF) capacity of L. gibba from water Elhovo is shown through its bioconcentration factors, indicating a decreasing order as follows:

\section{$\mathrm{Mn}>\mathrm{Fe}>\mathrm{Zn}>\mathrm{Cu}>\mathrm{Cr}>\mathrm{Cd}>\mathrm{Pb}>\mathrm{Ni}$}

These results show a correlation between a higher metal content in the water and hence a greater bioconcentration factor. Accumulation of metal in macrophytes depends on elements concentration in the water.

The bioconcentration capacity of $L$. gibba from water Mandra Lake is shown through its bioconcentration factors, indicating a decreasing order as follows: $\mathrm{Mn}>\mathrm{Fe}>\mathrm{Zn}>\mathrm{Cu}>\mathrm{Cr}>\mathrm{Pb}>\mathrm{Cd}>\mathrm{Ni}$

The differences of concentrations order of microelements in L. gibba from the two water bodies is only for $\mathrm{Cd}$ and $\mathrm{Pb}$. This can be explained by the eventuality exhibit synergism by $\mathrm{Cd}$ and Ni. Positive correlations were found between $\mathrm{Fe}, \mathrm{Zn}, \mathrm{Mn}$ and $\mathrm{Cu}$ contents in water and in plants.

The results obtained in table 3 show that $L$. gibba is more effective in the accumulation of metals compare to L. minor. Again, the bioconcentration capacity of $L$. gibba for $\mathrm{Mn}$ is thousand times higher than it is for the other metals. 
Similar results for the order of accumulation concentration of the metals in L. minor have been obtained Kastratović et al. (2015) in the study of Skadar Lake. Doganlar et al. (2012) investigated the effects of manganese and nickel on $L$. gibba under laboratory conditions. They received that $\mathrm{Mn}$ accumulation higher than $\mathrm{Ni}$, which agree with our results. Each of these heavy metals in any way negatively influencing on the duckweeds. Cadmium inhibited duckweed growth even at low concentrations. Copper was an essential element and has an important role in cellular metabolism at low concentrations (Khellaf et al. 2008). Zinc does not show any visible signs of toxicity but showed a reduction of biomass. Ni was toxic for the macrophytes and decreased considerably the growth rate. Chromium is dangerous heavy metal which causes membrane damage and growth inhibition (Sinha et al., 2005). $\mathrm{Pb}$ produced toxic effects on chlorophylls content in $L$. gibba (Miranda et al. 2000). In these studied species, $L$. minor and L. gibba, the strongest bioaccumulation was observed in manganese and iron. These metals are necessary for the metabolism and can more easily to be absorbed from surrounding environment and transported to the green parts of the plants (Lasat 2010).

\section{Acknowledgements}

This research work was carried out with the support of the Faculty of Agriculture, Trakia University, Project No 2A/16.

\section{References}

Axtell R, Sternberg P \& Claussen K. 2003. Lead and nickel removal using Microspora and Lemna minor. Bioresource Technology 89 (1): 41-48.

Chaudhary E \& Sharma P. 2014. Duckweed Plant: a Better future option for phytoremediation. IJESE 2: 2319-6378.

Chawla G, Singh J \& Viswanathan P. 1991. Effect of pH and temperature on the uptake of cadmium by Lemna minor L. Bulletin of Environmental Contamination and Toxicology 47(1): 84-90.

Doganlar Z, Cakmak S \& Yanik T. 2012. Metal Uptake and Physiological Changes in Lemna gibba Exposed to Manganese and Nickel. International Journal of Biology 4 (3): 148-157.

Drost W, Matzke M \& Backhaus T., 2007. Heavy metal toxicity to Lemna minor: studies on the time dependence of growth inhibition and the recovery after exposure. Chemosphere 67: 36-43.

Driever S, Egbert H \& Rudi M. 2005. Growth limitation of
Lemna minor due to high plant density. Aquatic Botany 81: 245-251.

Gijzen H \& Kondker M. 1997. An Overview of the Ecology, Physiology, Cultivation and Application of Duckweed in Caption Report. Annex-1, Literature Review. Duckweed Research Project (DWRP). Dhaka, Bangladesh.

Hach Lange. 2007. DR 2800 Spectrophotometer. Procedures manual. Germany, $814 \mathrm{pp}$.

Hammouda O, Gaber A \& Abdel-Hameed M. 1995. Assessment of the effectiveness of treatment of wastewater-contaminated aquatic systems with Lemna gibba. Enzyme and Microbial Technology 17 (4): 317-323.

Hawker D \& Connell D. 1991. An evaluation between bioconcentration factor and aqueous solubility. Chemosphere 23: 231-241.

Hou W, Chen X, Song G , Wang Q \& Chang C. 2007. Effects of copper and cadmium on heavy metal polluted waterbody restoration by duckweed (Lemna minor). Plant Physiology and Biochemistry 45: 6269.

Jayasri M \& Suthindhiran K. 2017. Effect of zinc and lead on the physiological and biochemical properties of aquatic plant Lemna minor: its potential role in phytoremediation. Applied Water Science 7 (3): 1247-1253.

Kastratović V, Jaćimović Ž, Đurović D, Bigović M, Krivokapić S. 2015. Lemna minor L. as bioindicator of heavy metal pollution in Skadar lake (Montenegro). Kragujevac Journal of Science 37: 123-134.

Kaur L, Gadgil K \& Sharma S. 2013. Effect of pH on nickel removal by Lemna minor. Journal of Solid Waste Technology and Management 39(3):190-196.

Khellaf N, Zeradaoui M, Faure O \& Leclerc J. 2008. Tolerance to heavy metal in the duckweed, Lemna minor. Environment International, 34, 1022-1026.

Körner S, Das S, Vernaat J \& Veenstra S. 2001. The effect of $\mathrm{pH}$ variation at the ammonium/ammonia equilibirium in wastewater and its toxicity to Lemna gibba. Aquatic Botany, 71:71-78.

Lasat M. 2010. Phytoextraction of metals from contaminated soil: A review of plant/soil/metal interaction and assessment of pertinent agronomic issues. Journal of Hazardous Substance Research 2: 1-25.

Miranda G, Quiroz A \& Salazar M. 2000. Cadmium and lead removal from water by the duckweed. Lemna gibba L. (Lemnaceae). Hidrobiológica 10 (1): 7-12.

Nayyef M, Azeez A \& Sabbar A. 2012. Efficeincy of Lemna minor L. in the Phytoremediation of waste water pollutants from Basrah oil refinery. Journal of Applied Biotechnology in Environmental Sanitation 1 (4): 163-172.

Patel DK \& Kanungo VK. 2010. Phytoremidation Potential of Duckweed (Lemna minor L.: A tiny aquatic plant) in the removal of pollutants from domestic wastewater with special reference to nutrients. The Bioscan 5 (3): 355- 358.

Singh D, Gupta R \& Tiwari A. 2012. Potential of duckweed (Lemna minor) for removal of dead from wastewater by phytoremediation. Journal of Pharmacy Research 5(3):1578-1582. 
Sinha S, Saxena R \& Singh S. 2005. Chromium induced lipid peroxidation in the plants of Pistia stratiotes L.: role of antioxidants and antioxidant enzymes. Chemosphere 58: 595-604.

Ugya Y. 2015. The Efficiency of Lemna minor L. in the Phytoremediation of Romi Stream: A Case Study of Kaduna Refinery and Petrochemical Company Polluted Stream. Journal of Applied Biology and Biotechnology 3 (1): 011-014.

Van Hoeck A, Horemans N, Monsieurs P, Cao H, Vandenhove H \& Blust R. 2015. The first draft genome of the aquatic model plant Lemna minor opens the route for future stress physiology research and biotechnological applications. Biotechnology for Biofuels 8: 188.

Velichkova K, Sirakov I, Valkova E, Stoyanova S \& Kostadinova G. 2017. Bioacumulation and protein content of Lemna minuta Kunth and Lemna valdiviana Phil. in Bulgarian water reservoirs. Scientific Papers. Series E. Land Reclamation, Earth Observation \& Surveying, Environmental Engineering 4: 104-107. 